\title{
Family Business Control, Strategy Selection and Strategic Performance Measurement Usage
}

\author{
Antonius Singgih Setiawan ${ }^{1}$, Agustinus Widyartono², and Johan Gunady Ony ${ }^{3}$ \\ ${ }^{1,2,3}$ Fakultas Bisnis Akuntansi,Universitas Katolik Musi Charitas \\ Email Address: \\ singgih@ukmc.ac.id
}

\begin{abstract}
Firms that are managed by family businesses have developed and have an impact on the growth of a country's economy. The family business has been a concern in much of the research literature. The development of family businesses also has an interesting phenomenon related to business governance systems, especially in management control systems. Therefore, this study aims to examine the effect of the owner's role in the management of the family business, and the strategy selection on to use of strategic performance measurement on the family business. The research was conducted using quantitative methods primary data through a survey of micro, small and medium entrepreneurs in the city of Palembang. A total of 150 questionnaires were distributed to entrepreneurs. The number of questionnaires used in this study was 107 (71\%). ANOVA analysis was used to test the hypothesis. The results showed that the role of the owner in controlling the family business and the strategy selection affected the strategic performance measurement.
\end{abstract}

Keywords: family business, strategic performance measurement usage, strategy selection.

\begin{abstract}
Abstrak: Perusahaan yang dikelola oleh bisnis keluarga telah berkembang dan membawa dampak pada pertumbuhan ekonomi sebuah negara. Bisnis keluarga telah menjadi perhatian dalam banyak literatur penelitian. Berkembangnya bisnis keluarga juga memiliki fenomena menarik yang berhubungan dengan sistem tata kelola bisnis, khususnya pada sistem pengendalian manajemen perusahaan. Oleh karena itu, penelitian ini bertujuan untuk menguji pengaruh peran pemilik dalam pengelolaan bisnis keluarga, dan pilihan strategi pada keputusan penggunaan pengukuran kinerja strategis bisnis keluarga. Penelitian dilakukan dengan menggunakan metode kuantitatif data primer yang dikumpulkan menggunakan survei pada pengusaha mikro, kecil dan menengah di kota Palembang. Sebanyak 150 kuesioner dibagikan kepada pengusaha. Jumlah kuesioner yang digunakan dalam penelitian ini adalah 107 (71\%). Analisis ANOVA digunakan untuk menguji hipotesis. Hasil penelitian menunjukkan bahwa peran pemilik dalam pengendalian bisnis keluarga dan pilihan strategi berpengaruh pada penggunaan pengukuran kinerja strategis.
\end{abstract}

Kata Kunci: bisnis keluarga, penggunaan pengukuran kinerja strategis, pilihan strategi. 


\section{INTRODUCTION}

Today, family companies or family businesses have played an important role in the global economy (Helsen et al., 2016). The family business has also played an important role in the economic growth of a country (Ray et al., 2018). Family firms are generally present in most parts of the world (Tsao et al., 2017). A family firm is a company that is owned by one or more family members. Ownership and management are owned by one or more families. One or more families become the majority shareholder, and at least two family members are involved in managing the business (Kallmuenzer et al., 2018). Therefore, the family business is an interesting issue to discuss. The underlying thing is that the family business is part of a relatively new field of scientific study and is deeply in touch with various major business disciplines, such as human resource management, accounting, and marketing (Songini et al., 2013).

The structure of a family firm is different from that of a non-family company. The difference lies in the direct involvement of family members in business management (Tsao et al., 2017). A family business is more dominated by management from founder or owners (Laakkonen and Kansikas, 2011). Therefore, the family in the family business is a factor that has an important influence in determining the implementation of the company's control system (Heinicke, 2018). Furthermore, (Sbarba and Marelli, 2018) explain that the characteristics of family business management can have a different effect on control practices in companies than in non-family company management.

This is supported by (Shahzad et al., 2019) which explain that the discussion about strategic decisions related to financial matters as well as corporate accounting practices in family and non-family controlled businesses has become a very important theme today. Another characteristic of the differences between family and non-family businesses can be seen based on considerations in strategic decision making. (Senftlechner and Hiebl, 2015) explain that in strategic decision making, family firms consider a longer time horizon than non-family firms. This is because decisions made by family companies can have an impact on future generations of the business.

The growth of family businesses in Indonesia has increased greatly. Many large companies were built from family businesses, such as Djarum, Bakri, Sampoerna, and so on. (Remiasa and Wijaya, 2014) explain that $95 \%$ of companies in Indonesia are family companies whose management is controlled by the family members of the company owners. Almost all Small and Medium Enterprises (SMEs) in Indonesia are a form of the family business. SMEs are one type of business that is growing rapidly, especially in developing countries (Afriany et al., 2019). Likewise in Palembang, UKM has grown rapidly. Currently, 37,351 SMEs are carrying out business activities in Palembang City as businesses in the form of family firms (Suud, 2020).

The growth and development of the family business also have an interesting phenomenon related to the business governance system, especially in the company's management control system. Globally, the topic of family business has attracted the attention of many researchers (Miller et al., 2018). (Speckbacher and Wentges, 2012) offer an analysis to see the relationship between family involvement in corporate management as a main characteristic of governance and the control characteristics of corporate management. In more detail, (Speckbacher and Wentges, 2012) analyzed the relationship between the involvement of founding family members in family firms as a 
characteristic of corporate governance with the use of a strategic performance measurement system.

Themes such as research on the relationship between the involvement of family company founding members in company management are still very interesting to study. The family of company founders often wants to keep their power in controlling the business. This is very relevant to the literature on the relationship between owner power on goal alignment to company management (Turner and Guilding, 2010). Owner's power in the aspect of power-sharing relations which by (Hofstede, 2011) is operationalized as power distance, and, according to a contingency perspective, is a derivative of the concept of national culture, when it can be operationalized into a model of the relationship between power owners and the orientation of corporate strategy towards the implementation of strategic management accounting in this is the implementation of the use of a performance measurement system.

Therefore, the owner's power which is reflected in the owner's involvement in corporate business governance is relevant to see whether it will have an impact on the choice of using a strategic performance measurement system which is one of the characteristics of strategic management accounting implementation. However, (Kotey and Meredith, 1997); (Kadir, 2014) have explained that the personality values of company owners, especially those who then have an intense involvement in corporate governance activities, have the potential to influence the orientation of the company's business strategy.

On the other hand, (Kober et al., 2007) explain that the use of management accounting instruments, as well as the use of strategic performance measurement systems, will be largely determined by the type of strategy chosen by each company management. The results of this study indicate that there is a logical relationship that there is a series of phenomena that the owner's involvement in business governance will have an impact on the choice of management accounting instruments. However, among these relationships, there is one important factor that can provide strength or weakness in the relationship between the two, namely the strategic choice factor implemented by the company. Based on this background, research on the relationship between control practices in the family business, the choice of strategy, and the use of strategic performance measurement will be interesting to do, especially when viewed in the context of the family business in Palembang.

\section{THEORETICAL REVIEW}

The family business control. (Quinn et al., 2018) explained that the development of the literature has shown clearly that family firms have a big difference in the design and use of management accounting and the implementation of its control system for non-family firms. Previously, (Senftlechner and Hiebl, 2015) explained that the fundamental characteristics of family businesses, among others, are family firms have a potential influence on the implementation of management control and management accounting systems. However, (Mustakallio et al., 2002) also explained that the basic characteristics of a family business can be seen based on company ownership, ownership involvement in management, transfer of business management from generation to generation, the existence of family intentions to continue the company as a family business, focus on 
family goals, and the occurrence of interactions between families and the business being run.

On the other hand, (Senftlechner and Hiebl, 2015) also explain that, in a family business, the implementation of management control will be carried out more informally. This is because management positions will be held by family members based on the trust given by fellow members of the company's management team. The interrelated nature of the family business system not only has an impact on agency conflicts in family companies, and this distinguishes family companies from non-family firm forms (Helsen et al., 2016). This is because the identity of family members is often closely related to the company, a strong emotional attachment appears in the family company which will significantly influence decision making in the company (Helsen et al., 2016).

Firms that are controlled by the founding family are likely to be related to the role of the family in managing the business even though the business is managed by management outside the family, this is because they feel they are the creators and the caregiver family (Pham et al., 2019). This is as explained by (Basco and Calobro, 2016) that the involvement of the family in business activities can affect the dominance of the owner in managing the business. When the family has a dominant role in business management, management must take into account various goals based on the needs of the business owner, therefore, the balance between the family of the owner and business goals will greatly affect the business management process (Basco and Pérez Rodríguez, 2011).

Strategy selection. Owners in family firms often play an important role in determining company strategy such as business downsizing, merger decisions, even diversification and internationalization of the business that is being carried out (Fairclough and Micelotta, 2013; Munoz-Bullon et al., 2018). However, (Basco, 2014) explains that family companies have a characteristic that they often choose to implement innovative strategies that are not risky, but at the same time they will try to maintain their reputation and try to be closer to customers and suppliers. The family as the main stakeholder in the family company can influence the company's innovative behavior, and open innovation strategies are very useful for family companies (Basco and Calobro, 2016). For that reason, (Brundin et al., 2014) explained that family and non-family companies may have different innovation strategies because each of them can be influenced by different goals.

In family businesses, there is a view that the descendants of the founders will often show an attitude of family altruism, they will view the family business as a mechanism for increasing income so that they are less tolerant of risky investments (Cheng et al., 2015). However, there is also a view that the founders will see the company as an asset that must be passed on to the next generation thus encouraging managers to make longterm investment decisions (Sacristán-Navarro et al., 2011). Another point about strategy is described by (Gimbert et al., 2010) stated that the process of determining the strategy describes a process that must be carried out by companies to define the objectives and scope of their business. This has also happened to family businesses as indicated by the effect of family ownership on technological innovation strategies, including R\&D investment (Tsao et al., 2017).

Therefore, the literature on strategy choice orientation reveals that strategy can be seen based on two typologies of strategy, namely cost leadership and differentiation 
strategy (Teeratansirikool et al., 2013). On the other hand, (Cinquini and Tennuci, 2010) show that the orientation of strategy choice can be seen in the characteristics of prospector strategies that focus on innovation and defender strategies that are more focused on efficiency. However, the field of strategic management operations and the concept of operating strategy have evolved to link operational activities to the company's long-term performance and increased competitiveness (Aghajari and Senin, 2013). For this reason, companies that have alignment between and consistency between operations and strategy will have a superior advantage over their competitors (Aghajari and Senin, 2013). This is because the strategic orientation of the company will be directly related to innovation in service quality and performance (Ramayah et al., 2011).

Strategic performance measurement usage. At present, there have been many studies that discuss family firms that tend to choose a performance measurement system to see their performance (Speckbacher and Wentges, 2012). Family involvement as a potential strategic resource has been considered a source of sustainable competitive advantage (Speckbacher and Wentges, 2012). On the other hand, firm management has two important responsibilities, namely on the internal side, controlling the business unit and external responsibility for reporting and communicating performance to interested parties, and the adoption of the use of strategic performance measurement Balanced Score Card (BSC) will have a big impact in all of them (Kraus and Lind, 2010).

BSC is a general framework on a common theme and vision that must be implemented and developed in each business unit (Kraus and Lind, 2010). BSC is a performance measurement system that has several dimensions that can balance objective and subjective measures, and can track past events, and can provide measures that drive future performance (Kaplan and Norton, 2006). A good strategy does not guarantee business success unless there is success in the proper implementation of the management control system, which includes the implementation of strategic performance measures (Ho et al., 2014).

On this side, BSC is believed to be a strategic performance measurement system because BSC is believed to be able to assist each company's business management in implementing and developing various company strategies that focus on coordination of several strategic business units (Kraus and Lind, 2010). BSC has four strategic measurement perspectives, namely, financial performance measures, customer performance measures, internal business process performance measures, and learning and growth performance measures (Kaplan and Norton, 2006). Added by (Raval et al., 2019), BSC's approach to financial measures shows the results of actions taken and nonfinancial measures concentrate on internal processes, customer satisfaction, and innovation and improvement. Therefore, the BSC method provides a major advantage for management, which is only measuring factors that are directly related to organizational strategy and not measuring everything (Punniyamoorthy and Murali, 2008). For this reason, BSC is more focused on helping management to add value to the company (Raval et al., 2019).

Therefore, strategic performance measurement has been widely read by experts and written in the literature because strategic performance measurement can drive strategy implementation. Also, strategic performance measurement can assess a manager's strategic focus, clarify and improve the company's communication strategy, ultimately 
strategic performance measurement will align people's behavior with the company's strategic goals (Franco-Santos et al., 2012). The main benefits of BSC are providing a systematic vision of operational performance, providing strategic updates and validation, providing speed in adopting strategic decisions quickly and widely, being able to integrate internal and external performance measures, encouraging increased productivity, and developing a learning culture, BSC also has the flexibility and ability adapt to various types of organizations and have a strong concern for customers and markets (Hoque, 2014).

\section{Research hypothesis.}

The role of the owner in managing the family business affects the decision to use the strategic performance measurement of the family business. (Speckbacher and Wentges, 2012) explain that, if the family owner also serves as an executive, there will be a tendency for managers to be reluctant to bear the costs of making entrepreneurial insights for known to people outside the family members in their company. This seems relevant to the concept of owner power in the study of (Turner and Guilding, 2010). In another explanation, (Turner and Guilding, 2010) state that management will tend to spend maximally owner's capital to support performance achievement, while owners demand capital savings for the benefit of the owner. This illustrates that the owner's involvement in business management will tend to see short-term and efficiency aspects.

On the other hand, family in business is an important factor in the implementation of the control system (Heinicke, 2018). The character of the family business can have a different effect on control practices in the company than in the management of nonfamily companies (Sbarba and Marelli, 2018). The findings of (Shahzad et al., 2019) explain that strategic decisions related to financial matters and corporate accounting practices are controlled by families. Based on this description, the hypotheses to be proven in this study are:

H1: The role of the owner in managing the family business affects the decision to use the strategic performance measurement of the family business.

The strategy selection in the family business affects the decision to use strategic performance measurement in the family business. (Chen and Tan, 2013) explain that companies with the owner role type who think strategically will implement just in time better than companies with the opposite type of owner role. This shows that the type of owner's role in managing the family business will have a major impact on their choice of strategic management accounting models. One of them is the application of business performance measurement options.

However, the strategy selection will contribute to influencing the relationship between the role of family members in business management and the use of strategic performance measurement. This is as explained in the findings of (Kotey and Meredith, 1997) and (Kadir, 2014) that the owner's personality values to their involvement in corporate governance activities will have the potential to influence the orientation of the company's business strategy, meanwhile, the use of management accounting instruments, 
as well as system use of strategic performance measurement, will be largely determined by the type of strategy chosen by each company management (Kober et al., 2007).

This finding is supported by the research results of (Carney et al., 2011) which explained that company strategy and the role of the family in business management affect company performance. The findings of (Diéguez-Soto et al., 2019) explain that the company's innovation strategy also has an impact on the role of the family in business management and company performance. Company performance is reflected in the choice of using company performance measurement. Based on these descriptions, the hypotheses to be proven in this study are:

H2: The strategy selection in the family business affects the decision to use strategic performance measurement in the family business.

\section{METHODS}

Population, sample, and data collection method. The study population was entrepreneurs who run businesses in Palembang City. The research sample is entrepreneurs who run a business through micro, small and medium enterprises in the city of Palembang. Data collection was carried out for approximately 4 weeks from the second week of January 2021 to the second week of February 2021. Table 1 shows the number of questionnaires distributed. The survey was conducted on entrepreneurs who run businesses through micro, small, and medium enterprises in Palembang city. A total of 150 questionnaires were delivered to respondents, however, 107 questionnaires were returned and could be analyzed in the data processing process. The response rate in this study at $71 \%$. Another 43 questionnaires did not return for various reasons and could not be processed in the research data processing.

Table 1. Questionnaire Distribution

\begin{tabular}{lc}
\hline \multicolumn{1}{c}{ Explanation } & $\begin{array}{c}\text { Number of } \\
\text { questionnaires }\end{array}$ \\
\hline Number of survey questionnaires delivered to respondents & 150 \\
Number of questionnaires that were not returned & 43 \\
Number of questionnaires returned and analyzed & 107 \\
Response rate & $71 \%$ \\
\hline Soute: & Primry
\end{tabular}

Source: Primary data processed

Data analysis method. Hypothesis testing is done using the ANOVA test, this is done because this study using the dependent variable on the metric scale, and more than one independent variable with a non-metric scale. The criteria for acceptance or rejection of a hypothesis are based on the p-value. If the p-value $F$ is calculated $<0.05$ then the hypothesis (HA) is accepted. Before the ANOVA test, the ANOVA assumption test was performed using the Homogeneity of Variance test. 
Homogeneity of Variance test is conducted to see that the dependent variable has the same variance in each category of the independent variable. If there is more than one independent variable, then there must be a homogeneity of variance in cells formed by categorical independent variables. The homogeneity of variance test was carried out using the Levene's test of homogeneity of variance with the criteria that if the p-value < 0.05 then the null hypothesis would be rejected, which means that the group has different variances and this violates the assumption, while what is expected is $p$-value $>0.05$ so that each group has the same variance.

The role of owner. Based on the dummy indicator used by (Speckbacher and Wentges, 2012), namely 1 if the management of the company is dominated by the owner's family and 0 if there is the involvement of business management by people outside the family.

Strategy selection. Following (Cinquini and Tennuci, 2010) a defender strategy is defined as a business characterized by constant competition, a relatively stable set of products/services, tends to strive for efficiency and is specialized, and is a centralized organization. Instead, a prospector strategy defined as a business characterized by dynamic competition, relatively frequent changes in the product/service set, is always continuing to be a pioneer in new market areas, and having a flexible structure. The selection of the assessment strategy used the instrument used by (Cinquini and Tennuci, 2010) by asking respondents to describe the strategic priorities with a 6-point Likert scale. The research data will be in the form of the dummy ( 1 if choosing a prospector strategy and 0 if a defender strategy).

Strategic performance measurement usage. Referring to (Kaplan and Norton, 2006) as well as research by (Speckbacher and Wentges, 2012) the use of strategic performance measurement is seen based on the total use of four strategic performance measurement perspectives which include the use of financial and non-financial performance measures, namely (1) financial measures, (2) customer value, (3) company business processes, (4) capacity of company personnel. The research data will be in the form of an index of the use of performance measures based on how many types of measures are used.

\section{RESULT}

Table 2. Respondent Profile

\begin{tabular}{lccc}
\hline Respondent Profile & Number & Percentage (\%) & \\
\hline Gender & 42 & 39.3 & \\
Female & 65 & 60.7 & \\
Male & & & \\
Length of Business & 15 & 14.1 & \\
Less than 5 years & 36 & 33.6 & \\
$5-10$ years & 24 & 22.4 & \\
10 - 15 years & 32 & Oldest & Average \\
More than 15 years & Youngest & 75 & 45 \\
\cline { 2 - 4 } & 20 & & \\
\hline
\end{tabular}

Source: Primary data processed 
Descriptive statistics. To provide a descriptive description of the respondent's demographics and the variables used in this study, the following will describe the demographic characteristics of the respondents, the distribution of the theoretical range and the actual range as well as the mean and standard deviation of the dependent variable. Data described based on the percentage of the categorical frequency of each variable.

Table 2 shows the number of respondents who participated in this study as many as 107 respondents, with an average age of 45 years or ranging from 20 to 75 years of age. This data informs that entrepreneurs who run family businesses in the city of Palembang are on average at a productive age. The youngest age of entrepreneurs, at the age of 20 , also shows that business activities have begun to be carried out by those belonging to the millennial age group.

Table 2 also shows the demographics of the respondents by gender. The number of female respondents was 42 people $(39.3 \%)$, male respondents were 65 people $(60.7 \%)$. This information confirms that the male gender group still dominates the role of business management in Palembang city. This data is also a challenge for women to be able to increase their role in building and managing businesses. This needs to be done to achieve gender equality in managing a business at the local level.

Finally, Table 2 informs the length of time the business has been run. This study identifies the length of time the business has been run in 4 categories, namely (1) less than 5 years there are 15 companies $(14.1 \%)$, (2) between 5 - 10 years there are 36 companies $(33.6 \%)$, (5) between 10 - 15 years there were 24 companies $(22.4 \%)$, (4) more than 15 years there were 32 companies (29.9\%). This data indicates that the existing company has been running for a long duration of time. The majority of companies have been running for 5 - 10 years and are followed by companies that have been running for more than 15 years. This also shows that the companies that participated in this study were companies that had relatively stable and good survival.

Table 3. Strategic Performance Measurement Usage

\begin{tabular}{lcccc}
\hline Variable & $\begin{array}{c}\text { Theoretical } \\
\text { Range }\end{array}$ & $\begin{array}{c}\text { Actual } \\
\text { Range }\end{array}$ & Mean & $\begin{array}{c}\text { Standard } \\
\text { Deviation }\end{array}$ \\
\hline Strategic performance measurement usage & $1-4$ & $1-4$ & 2.52 & 1.144 \\
\hline Source: Primary data processed & & & &
\end{tabular}

Table 3 can be seen the descriptive statistics for the dependent variable data. The data on the use of strategic performance measurement shows an average index value of 2.52 with a theoretical range of $1-4$ and an actual range of $1-4$. The index for the use of strategic performance measurement is calculated based on 4 indices of strategic performance measures which include the use of financial and non-financial performance measures. The average index score of 2.52 indicates that the majority of family businesses prefer 2 to 3 measures of performance alone. The data show that the most widely used measure is the financial measure, followed by the customer value measure. The size of the business process and the size of the personal capacity are relatively few. However, research data shows that the majority of companies have combined financial and non-financial measures in managing their business. 
Table 4. Role of Owner and Strategy Selection

\begin{tabular}{lcc}
\hline Variable & Number & Percentage (\%) \\
\hline Role of owner & & \\
$\quad$ Main family & 90 & 84.1 \\
$\quad$ Outside the main family & 17 & 15.9 \\
Strategy selection & 64 & 60.7 \\
$\quad$ Prospector & 42 & 34.3 \\
$\quad$ Defender & & \\
\hline
\end{tabular}

Source: Primary data processed

Table 4 shows the categorical data for the role of owner variable and strategy selection. The role of the owner in managing the family business is identified in the category of who is the main management in the company. This study identifies the main management in the choice of the main family or outside this family, the main family is defined as a family member of one degree up or one degree below, the main family is husband-wife, parents, or biological children. The data shows that the majority of companies surveyed in this study are more dominated by being led by part of the main family, namely as many as 90 companies (84.1\%), the remaining $17(15.9 \%)$ companies are led by people from outside the main family. These findings indicate that there are still many family businesses that have not entrusted business management to external parties.

Strategy selection variables were identified based on the choice of prospector and defender strategies. Table 4 shows that the majority of family businesses in Palembang have chosen to implement the prospector strategy of 64 companies $(60.7 \%)$. The rest, 42 companies $(34.3 \%)$ still choose a defender strategy. This finding informs that many family businesses have chosen strategies for long-term orientation, seeing innovation and creativity as options that must be implemented to face competition. This condition also shows that the management of the family business has led to a modern strategic model that is oriented towards competition and competitive advantage.

Table 5. Lavene Statistic Test

\begin{tabular}{ccc}
\hline Dependent Variable & Lavene Statistic & p-value \\
\hline Strategic performance measurement usage & 0.952 & 0.418 \\
\hline Source: Primary data processed & &
\end{tabular}

Uji Homogeneity of Variance. Table 5 is the results of the Homogeneity of Variances test on the ANOVA test of the influence of family roles and the strategy selection on the strategic performance measurements usage, it can be seen that the results of the Homogeneity of variances test for the dependent variable of family business control practices show the Lavene Statistical value of 0.952 with a p-value of 0.418 . The Lavene test results show a p-value $>0.05$, so it can be concluded that the assumption of variance for the dependent variable for each category is homogeneous is acceptable. Therefore, ANOVA analysis for this study can be continued. 


\section{DISCUSSION}

Table 6. ANOVA Test

\begin{tabular}{lcc}
\hline \multirow{2}{*}{ Source } & \multicolumn{2}{c}{ Strategic performance measurement usage } \\
\cline { 2 - 3 } Intercept & $\mathrm{F}$ test & $\mathrm{p}$-value \\
\hline Role of owner & 893.743 & $0.000^{* * *}$ \\
\hline Strategy selection & 238.228 & $0.000 * * *$ \\
\hline & 11.001 & $0.001 * * *$ \\
\hline$* * *$ significant at 1\% & $\mathrm{R}^{2}=0.709\left(\mathrm{Adj} . \mathrm{R}^{2}=0.703\right)$ \\
Source: Primary data processed & &
\end{tabular}

Hypothesis 1. Based on the results of the ANOVA test in Table 6, the role of the owner has a statistically significant effect on the use of strategic performance measurement in the family business. This statistically significant effect can be seen based on the F value of 238,228 with a p-value of 0,000 or below a significance of 0.01 . These findings support the research hypothesis which states that the role of the owner in the management of the family business affects the decision to use the strategic performance measurement of the family business. These findings confirm the findings of (Sbarba and Marelli, 2018) which explain that the characteristics of family business management can influence control practices in companies, including determining the use of a performance measurement system.

This finding also supports (Speckbacher and Wentges, 2012) who explain the involvement of founding family members in family firms as a characteristic of corporate governance with the use of a strategic performance measurement system. The role of the owner in managing the business is a common thing. However, the owner's strategic vision will determine strategic system and method choices for increasing the company's capacity. This research has succeeded in identifying the owner's strategic vision in determining the business governance process. The empirical research data shows that the majority of family business owners have chosen a prospector strategy and have chosen to use business strategic performance measures to assess the progress of the business they are running.

Therefore, this finding also strengthens the explanation of (Quinn et al,, 2018) that the development of the literature has clearly shown that family companies have played a major role in the decision to use management accounting and the implementation of a business management control system. Family in the family business has also become a factor that has an important influence in determining the implementation of the company's control system (Heinicke, 2018) including determining a business performance measurement system based on the company's strategic vision.

Hypothesis 2. Based on the results of the ANOVA test in Table 6, it can also be seen that the choice of strategy statistically has a significant effect on the use of strategic performance measurement in family businesses. This statistically significant effect can be seen based on the F value of 11.001 with a p-value of 0.001 or below the significance of 0.01. These findings support the research hypothesis which states that the choice of strategy in family business management affects the decision to use strategic performance 
measurement for family businesses. These findings confirm (Kober et al., 2007) who concluded that the use of management accounting instruments, as well as the use of strategic performance measurement systems, will be largely determined by the type of strategy chosen by each company management. This also supports (Kadir, 2014) explanation that the personality values of company owners, especially those who have an intense involvement in corporate governance activities, have the potential to influence the orientation of the company's business strategy.

Previous findings were explained by (Carney et al., 2011) that corporate strategy and the role of the family in manage of business affect company performance. The findings of (Diéguez-Soto et al., 2019) explain that the company's innovation strategy also has an impact on the role of the family in the management of the business. The two explanations also confirm that the relevant strategic selection will have a positive impact on the achievement of the firm's business performance. However, good business performance can be seen if the company has implemented the right performance measurement system. The findings of this study are important because they successfully confirm all the literature that shows a positive relationship between the choice of strategy and the choice of control systems and the firm's performance measurement systems.

Once again, empirical data show that the majority of entrepreneurs who manage family businesses have chosen the prospector strategy that is oriented towards long-term, innovative and creative choices by (Cinquini and Tennuci, 2010). On the other hand, empirical research data also shows that the majority of entrepreneurs in family businesses have implemented a strategic performance measurement system that is oriented towards financial and non-financial performance measures (Speckbacher and Wentges, 2012). Finally, these two findings increasingly show that the influence and role of the owner in instilling a strategic vision in the family business manager will have a positive impact in determining the choice of company strategy and the choice to determine the proper management control system. A good management control system can be reflected in the decision to implement a firm's strategic performance measurement system.

\section{CONCLUSION}

This study concludes that the role of the owner and the strategy selection on family business control practices has an impact on the use of strategic performance measures. The stronger the role of the owner and the choice of prospector strategies in family business management will increase the implementation of the use of strategic performance measurement. The conclusion of this study shows that the management of family businesses in the city of Palembang has shown the implementation of a strategic business vision.

The findings of this study provide important implications in modern business management, especially in family business management. The family business has been managed using a modern management control system. Family businesses have been run by implementing a set of competitive strategies. Family businesses that do not implement a strategic vision will find it difficult to face increasingly dynamic competition. For this reason, family business actors must be able to respond to increasingly dynamic 
challenges and business competition by implementing a strategic management control system, and the use of a strategic-oriented performance measurement system.

However, this research also still has several limitations that should be of concern for improvement in future research. This study only looks at the impact of the owner's role and the choice of family business strategy on the use of strategic performance measurement. This study has not looked at how it impacts the achievement of business performance. For this reason, suggestions that can be considered in future research are that future research needs to look at the achievements of business performance to prove the concrete impact role of owner, strategic choices, and the use of strategic performance measurements on the achievement of family business performance.

\section{REFERENCES}

Afriany, A. N., Budiarto, D. S., and Putri, A. N. A. (2019). Hubungan antara kepemilikan keluarga dengan kesuksesan bisnis pada usaha kecil \& Menengah (UKM). Akuntansi Dewantara, 3(1), 67 - 74.

Aghajari, N., and Senin, A. A. (2013). Strategic orientation and dual innovative operation strategies: Implications for performance of manufacturing SMEs. Asia-Pacific Journal of Business Administration, 6(2), 127 - 147.

Basco, R. (2014). Exploring the influence of the family upon firm performance: does strategic behavior matter? International Small Business Journal, 32(8), 967 - 995.

Basco, R., and Calobro, A. (2016). Open innovation search strategies in family and nonfamily SMEs. Academia Revista Latinoamericana de Administración, 29(3), 279 302.

Basco, R., and Pérez Rodríguez, M. . (2011). Ideal types of family business management: Horizontal fit between family and business decisions and the relationship with family business performance. Journal of Family Business Strategy, 2(3), 151 165.

Brundin, E., Samuelsson, E. ., and Melin, L. (2014). Family ownership logic: framing the core characteristics of family businesses. Journal of Management \& Organization, 2(1), 6-37.

Carney, M., Gedajlovic, E. ., Heugens, P. ., Van Essen, M., and Oosterhout, J. . (2011). Business group affiliation, performance, context, and strategy: A meta-analysis. Academy of Management Journal, 54(3), 437-460.

Chen, Z., and Tan, K. H. (2013). The impact of organization ownership structure on JIT implementation and production operations performance. International Journal of Operations \& Production Management, 33(9), 1202 - 1229.

Cheng, M., Lin, B., and Wei, M. (2015). Executive compensation in family firms: the effect of multiple family members. Journal of Corporate Finance, 32(1), 238-257.

Cinquini, L., and Tennuci, A. (2010). Strategic management accounting and business strategy: A loose coupling? Journal of Accounting \& Organizational Change, 6(2), $228-259$.

Diéguez-Soto, J., Manzaneque, M., Gonzalez-García, V., and Galache-Laza, T. (2019). A study of the moderating influence of $R \& D$ intensity on the family managementfirm performance relationship: Evidence from Spanish private manufacturing firms. BRQ Business Research Quarterly, 22(2), 105-118. 
Fairclough, S., and Micelotta, E. . (2013). Beyond the family firm: reasserting the influence of the family institutional logic across organisations (Boxenbaum,). Institutional Logics in Action, Emerald Group Publishing.

Franco-Santos, M., Lucianetti, L., and Bourne, M. (2012). Contemporary performance measurement systems: A review of their consequences and a framework for research. Management Accounting Research, 23(2), 79-119.

Gimbert, X., Bisbe, J., and Mendoza, X. (2010). The Role of Performance Measurement Systems in Strategy Formulation Processes. Long Range Planning, 43, 477 - 497.

Heinicke, A. (2018). Performance measurement systems in small and medium-sized enterprises and family firms: a systematic literature review. Journal of Management Control, 28(4), 457 - 502.

Helsen, Z., Lybaert, N., Steijvers, T., Orens, R., and Dekker, J. (2016). Management control system in family firms: A review of the literature and directions for future. Journal of Economic Surveys, 31(2), 410 - 435.

Ho, J. L. Y., Wu, A., and Wu, S. Y. C. (2014). Performance measure, consensus on strategy implementation and performance: Evidence from the operational-level of organizations. Accounting Organizations and Society, 39(1), 38 - 58.

Hofstede, G. (2011). Dimensionalizing cultures: The hofstede model in context. Online Readings in Psychology Dan Culture, 2(1), Article 8.

Hoque, Z. (2014). 20 Years of Studies on the Balanced Scorecard: Trends, Accomplishments, Gaps and Opportunities for Future Research. The British Accounting Review, 46, 33-59.

Kadir, N. (2014). The influences of the performance of the owner's business and personality-based Small dan medium enterprises: A study on SME's in Sengkang regency. Journal of Business and Management, 16(4), 21 - 24.

Kallmuenzer, A., Hora, W., and Peters, M. (2018). Strategic decision-making in family firms: An explorative study. European Journal of International Management, $12(5-6), 655-675$.

Kaplan, R. ., and Norton, D. (2006). Alignment; Using the Balanced Scorecard to Create Corporate Synergies. Harvard Business School Press.

Kober, R., Ng, J., and Paul, B. J. (2007). The interrelationship between management control mechanisms and strategy. Management Accounting Research, 18(4), 425 452.

Kotey, B., and Meredith, G. G. (1997). Relationships among owner/manager personal values, business strategies, and enterprise performance. Journal of Small Business Management, 35(2), $37-61$.

Kraus, K., and Lind, J. (2010). The impact of the corporate balanced scorecard on corporate control-A research note. Management Accounting Research, 21, 265 277.

Laakkonen, A., and Kansikas, J. (2011). Evolutionary selection and variation in family businesses. Management Research Review, 34(9), 980-995.

Miller, D., Amore, M. ., Le Breton-Miller, I., Minichilli, A., and Quarato, F. (2018). Strategic distinctiveness in family firms: firm institutional heterogeneity and configurational multidimensionality. Journal of Family Business Strategy, 9(1), 16 -26 .

Munoz-Bullon, F., Sanchez-Bueno, M. J., and Suarez-Gonzalez, I. (2018). 
Diversification decisions among family firms: the role of family involvement and generational change. BRQ Business Research Quarterly, 21(1), 39 - 52.

Mustakallio, M., Autio, E., and Zahra, S. A. (2002). Relational and contractual governance in family firms: Effects on strategic decision making. Family Business Review, 15(3), $205-222$.

Pham, T. ., Bell, R., and Newton, D. (2019). The father's role in supporting the son's business knowledge development process in Vietnamese family businesses. Journal of Entrepreneurship in Emerging Economies, 11(2), 258 - 276.

Punniyamoorthy, M. R., and Murali, R. (2008). Balanced score for the balanced scorecard: A benchmarking tool. Benchmarking: An International Journal, 15(4), $420-443$.

Quinn, M., Hiebl, M. R. W., Moores, K., and Craig, J. B. (2018). Future research on management accounting and control in family firms: suggestions linked to architecture, governance, entrepreneurship and stewardship. Journal of Management Control, 28(4), 529 - 546.

Ramayah, T., Samat, N., and Lo, M. C. (2011). Market orientation, service quality and organizational performance in service organizations in Malaysia. Asia-Pacific Journal of Business Administration, 3(1), 8-27.

Raval, S. J., Kant, R., and R, S. (2019). Benchmarking the Lean Six Sigma performance measures: A balanced score card approach. Benchmarking: An International Journal, 26(6), 1921-1947.

Ray, S., Mondal, A., and Ramachandran, K. (2018). How does family involvement affect a firm's internationalization? An investigation of Indian family firms. Global Strategy Journal, 8(1), 73 - 105.

Remiasa, M., and Wijaya, S. A. (2014). Analsis proses suksesi perusahaan keluarga studi pada PT Putraasean. Kinerja, 18(2), 141 - 156.

Sacristán-Navarro, M., Gómez-Ansón, S., and Cabeza-García, L. (2011). Family ownership and control, the presence of other large shareholders, and firm performance: further evidence. Family Business Review, 24(1), 71-93.

Sbarba, A. D., and Marelli, A. (2018). Family-controlled businesses and management control: the framing of "shareholder-oriented" practices. Journal of Management Control, 28(4), 417 - 456.

Senftlechner, D., and Hiebl, M. (2015). Management accounting and management control in family businesses: Past accomplishments and future opportunities. Journal of Accounting \& Organizational Change, 11(4), 573 - 606.

Shahzad, F., Rehman, I., and Nawaz, F. (2019). Financial reporting quality, family ownership, and investment efficiency: An empirical investigation. Managerial Finance, 45(4), 513 - 535.

Songini, L., Gnan, L., and Malmi, T. (2013). The role and impact of accounting in family business. Journal of Family Business Strategy, 4(2), 71 - 83.

Speckbacher, G., and Wentges. (2012). The impact of family control on the use of performance measures in strategic target setting and incentive compensation: A research note. Management Accounting Research, 23, 34 - 46.

Suud, D. (2020). Lebih 163 Ribu UMKM Tumbuh di Sumsel, Paling Banyak di Palembang. https://indonesiainside.id/ekonomi/2020/02/20/lebih-163-ribu-umkmtumbuh-di-sumsel-paling-banyak-di-palembang 
Teeratansirikool, L., Siengthai, S., Badir, Y., and Charoenngam, C. (2013). Competitive strategies and firms performance: The mediating role of performance measurement. International Journal of Productvity and Performance Management, 62(2), 168 184.

Tsao, S. M., Chang, Y. W., and Koh, K. (2017). Founding family ownership and myopic R\&D investment behavior. Journal of Accounting, Auditing \& Finance, 34(3), 361 $-384$.

Turner, M. J., and Guilding, C. (2010). Hotel management contracts and deficiencies in owner-operator capital expenditure goal congruency. Journal of Hospitality Dan Tourism Research, 34(4), 168 - 184. 